\author{
Aleksandra Anna Kozłowska \\ Łódź
}

\title{
Bolesław Roja. Legionowym szlakiem dowódcy czwartaków
}

Legionista, generał, polityk - Bolesław Roja - nie doczekał się jak dotąd żadnego opracowania monograficznego czy nawet obszernego artykułu na swój temat. Hasła biograficzne jedynie ogólnie sygnalizują złożoność tej postaci ${ }^{1}$. Warto zatem zaprezentować przynajmniej fragment życiorysu B. Roi, którego losy silnie związały się z ziemią piotrkowską. Tutaj bowiem wiosną 1915 r. rozpoczął on organizację legendarnego 4 pułku piechoty Legionów Polskich²; oddziału, który znalazł się w składzie III Brygady.

Przyszły dowódca czwartaków przyszedł na świat 4 IV 1876 r. we wsi Bryńce Zagórne, pow. Bóbrka, w ówczesnej Galicji (ob. obwód lwowski na Ukrainie). Jego matką była Maria de domo Trzcińska. Ojciec, Józef, prowadził gospodarstwo, wykonywał również zawód leśnika. Przyszły dowódca 4 pp należał - obok Andrzeja Galicy (1873-1945) - do wyjątków, jakimi były osoby pochodzenia chłopskiego wśród generalicji okresu II Rzeczypospolitej. Wśród przodków B. Roi były także tradycje wojskowe, o czym sam wspominał: „Z rodziny po matce, córce drobnego hreczkosieja, Trzcińskiego spod Lwowa, po ojcu »z gór«, z rodziny żołnierzy, którzy, jak daleko akta i podania rodzinne sięgają, tłukli kości po całej Europie, odnosiłem się z zamiłowaniem i niemal nabożeństwem do zawodu żołnierza i do kawałka roli”’3.

Przyszły generał uczył się w gimnazjach we Lwowie i Krakowie. Uczęszczał do gimnazjum św. Anny (im. Bartłomieja Nowodworskiego), najstarszej i najlepszej szkoły średniej w Krakowie. Ukończyli ją również m.in.: Stanisław Wyspiański, Kazimierz Przerwa Tetmajer, Tadeusz Boy-Żeleński, późniejszy

1 H. Korczyc, Roja Bolesław (1876-1940), [w:] Polski Słownik Biograficzny, t. XXXI/1, z. 128, Wrocław-Warszawa-Kraków-Gdańsk-Łódź 1988, s. 508-511; P. Stawecki, Słownik biograficzny generałów Wojska Polskiego 1918-1939, Warszawa 1994, s. 278-279; J.M. Radomski, Bolesław Roja (1876-1940), [w:] Z walk II Brygady Legionów Polskich w Karpatach Wschodnich 1914/1915. Materiały pokonferencyjne, red. L. Fac, Przemyśl 2002, s. 123-124; W.K. Cygan, Oficerowie Legionów Polskich 1914-1917. Słownik biograficzny, t. IV, Warszawa 2006, s. 137-138.

2 W tekście użyto następujących skrótów: AOK - Armee-Oberkommando, ck - cesarsko-królewski, DP - Dywizja Piechoty, G.u.M. - Gedenkstätte und Museum, ITS - International Tracing Service (Archiwum w Bad Arolsen, Niemcy), LP - Legiony Polskie, MTN - Muzeum Tradycji Niepodległościowych, NKN - Naczelny Komitet Narodowy, pp - pułk piechoty.

$3 \quad$ B. Roja, Legioniści w Karpatach w 1914-1915 roku, Warszawa 1933, s. 8-9. 
marszałek Edward Śmigły-Rydz (1886-1941) czy generałowie: A. Galica (18731945), Józef Olszyna-Wilczyński (1890-1939), Stanisław Wróblewski (1868$1949)^{4}$. To właśnie w tym gimnazjum Bolesław eksternistycznie zdał maturę. Następnie, w latach 1895-1898, uczył się w szkole kadetów (Kadettenschule) w Wiener Neustadt koło Wiednia 5 .

Od 1899 r. B. Roja służył w armii austro-węgierskiej w stopniu podchorążego. Rok później - w stopniu podporucznika - znalazł się w szeregach 36 pp Obrony Krajowej (Landwehra). Jednostka ta stacjonowała w Kołomyi. W 1905 r. przeszedł do rezerwy. Przed wybuchem I wojny światowej awansował do stopnia porucznika ${ }^{6}$. Od 1906 r. był agentem wywiadu austriackiego. Jak podał gen. Maximilian Ronge, szef Biura Ewidencyjnego Sztabu Generalnego w Wiedniu i Oddziału Informacyjnego AOK (Naczelna Komenda Armii) w Baden, miał pracować również dla warszawskiej Ochrany ${ }^{7}$.

Po zakończeniu służby w ck armii B. Roja rozpoczął studia prawnicze, potem zaś medyczne na Uniwersytecie Jagiellońskim. Nie ukończył ich jednak. Pracował w magistracie krakowskim. Był urzędnikiem w Polskim Towarzystwie Emigracyjnym (założonym w 1908 r.), którego celem była opieka nad polskim wychodźstwem oraz utrzymywanie związków emigracji z krajem ${ }^{8}$.

W chwili wybuchu I wojny światowej wstąpił do Towarzystwa Gimnastycznego „Sokół” w Krakowie. Na polecenie inż. Władysława Turskiego (członek rady miejskiej Krakowa), prezesa „Sokoła” oraz naczelnika Szczęsnego Rucińskiego, przystąpił do szkolenia wojskowego Drużyn Sokolich. Na początku września 1914 r. objął na krótko dowództwo II batalionu 2 pp LP (dowódca - płk Zygmunt Zieliński), a następnie IV batalionu tej jednostki. Dowódcami pozostałych batalionów byli: I - kpt. Marian Żegota-Januszajtis, II - kpt. Kazimierz Fabrycy, III - kpt S. Ruciński9 .

W dniu 29 IX 1914 r. B. Roja otrzymał awans na kapitana. W szeregach 2 pp LP 1 października wyruszył z Dębnik pod Krakowem na front. Jednostka znalazła się 5 października na obszarze komitatu Marmaros-Sziget. Wraz z 3 pp przyszło jej walczyć w Karpatach. Stąd utworzona w przyszłości (maj 1915 r.) z tych wła-

4 J. Adamczewski, Kraków od A do Z, Kraków 1986, s. 90. W 1898 szkołę przeniesiono do nowego gmachu na pl. Na Groblach 9. Obecnie nosi nazwę I Liceum Ogólnokształcące im. B. Nowodworskiego.

5 CAW, Kolekcja generałów i osobistości - Roja Bolesław, Haupt-Grundbuchsblatt, 13 VI 1905. Na temat szkół kadeckich w ck monarchii zob. J. Rydel, W służbie cesarza i króla. Generałowie i admirałowie narodowości polskiej w siłach zbrojnych Austro-Węgier w latach 1868-1918, Kraków 2001, s. 94-95.

6 CAW, Kolekcja generałów i osobistości - Roja Bolesław, Haupt-Grundbuchsblatt, 13 VI 1905.

7 R. Świętek, Lodowa ściana. Sekrety polityki Józefa Piłsudskiego 1904-1918, Kraków 1998, s. 46-47.

8 H. Korczyc, dz. cyt., s. 508.

$9 \quad$ B. Roja, Legioniści w Karpatach..., s. 11-12, 32-35; D. Dudek, Działalność wojskowa Towarzystwa Gimnastycznego „Sokół” przed I wojnq światowq, Nowy Sącz 1994, s. 6; S. Czerep, II Brygada Legionów Polskich, Warszawa 2007, s. 33. 
śnie pułków II Brygada LP nazwana została Karpacką. Ze względu na jej bohaterstwo i waleczność doszło także inne, nieoficjalne określenie - Żelazna Bry$\operatorname{gada}^{10}$.

W drugiej połowie października 1914 r. B. Roja zajął osadę Sołotwinę. W 29 dniu tegoż miesiąca 2 i 3 pp wzięły udział w walkach pod Mołotkowem, gdzie starły się z Rosjanami. Pomimo determinacji i poświęcenia dowodzony przez B. Roję IV batalion 2 pp został zmuszony do odwrotu. Polacy ponieśli w boju bardzo duże straty (około 200 zabitych, prawie 500 rannych, 200 żołnierzy zaginionych i wziętych do niewoli; strona rosyjska -100 zabitych) ${ }^{11}$. Doceniono jednak męstwo B. Roi, który 11 XI 1914 r. otrzymał awans na majora ${ }^{12}$.

Podczas walk pod Mołotkowem B. Roja został szrapnelem ranny w lewą rękę. Przez jakiś czas nosił ją na temblaku, co potwierdza zachowana ikonografia. Przede wszystkim jednak był głęboko zawiedziony i rozczarowany działaniem Komendy LP. W opinii Roi klęska pod Mołotkowem była wynikiem niewłaściwych decyzji podjętych przez ten organ, m.in. - jak to określił dowódca IV batalionu 2 pp - niepotrzebnym mieszaniem batalionów czy brakiem dat w rozkazach. Krytycznie ocenił również działania Austriaków, którzy nawet nie wydali polskim żołnierzom dostatecznej ilości łopatek polowych, umożliwiających im okopanie $^{13}$.

Wydarzenia spod Mołotkowa stały się tematem wiersza, w którym pojawia się postać B. Roi oraz 15 kompania IV batalionu 2 pp:

\author{
„Hej, Mołotków zaszczytny \\ I pamiętny, i miły, \\ Tam to Legion nasz bitny \\ Na tysięczne szedł siły. \\ Ziały ogniem wciąż działa, \\ Ziemia drżała od stali, \\ Front piętnastka trzymała, \\ Ostro biła Moskali. \\ Bo piętnastka spod Roi \\ To żołnierze dobrani:
}

10 Tamże, s. 5.

11 Walki pułku II i III w Karpatach, „Wiadomości Polskie” nr 2, 12 XII 1914, Cieszyn, s. 4; W. Milewska, J.T. Nowak, M. Zientara, Legiony Polskie 1914-1918. Zarys historii militarnej i politycznej, Kraków 1998, s. 91-92. Nieco inne liczby: 200 zabitych, 300 rannych, 400 w niewoli podał Jeremiasz Ślipiec, Walki polsko-rosyjskie pod Mołotkowem (28-29 X 1914 r.) jako pierwsza wielka bitwa odradzajqcego się Wojska Polskiego, [w:] Z walk II Brygady Legionów..., s. 75.

12 Lista starszeństwa oficerów Legionów Polskich w dniu oddania Legionów Polskich Wojsku Polskiemu (12 kwietnia 1917), Warszawa 1917, s. 2.

13 Lista chorych, rannych, zabitych i zaginionych legionistów do kwietnia 1915 roku (wyd. przez Centralny Oddział Ewidencyjno-Werbunkowy Departamentu Wojskowego NKN), Piotrków Trybunalski 1915, s. 51; B. Roja, Legioniści w Karpatach..., s. 107-118, 123, 133 - fot.; T. Pelczarski, Sprawozdania. Bolesław Roja: Legioniści w Karpatach 1914-1915, Warszawa 1933 [rec.], s. 478. 


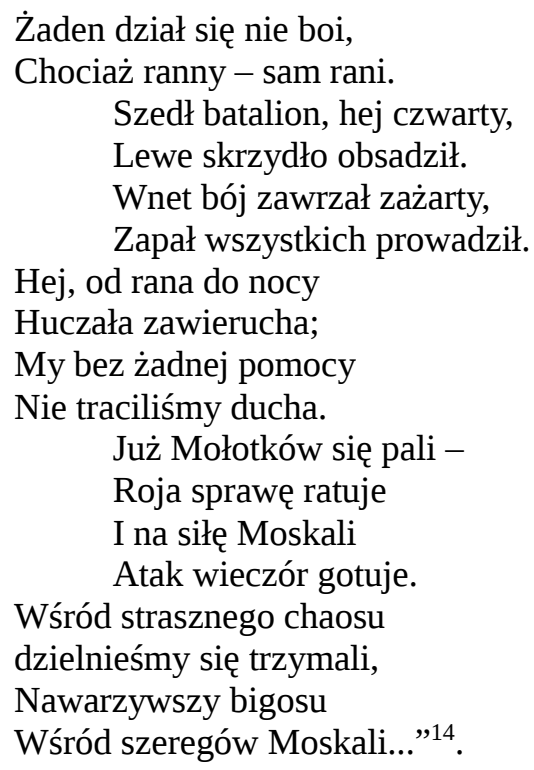

W dniu 26 XI 1914 r. AOK dokonała podziału LP walczących w Karpatach na 2 grupy. Większa z nich, dowodzona przez gen. por. Karola Trzaskę-Durskiego i licząca około 2800 żołnierzy, została skierowana do Żabiego i Kut na Bukowinie. Mniejsza, z Józefem Hallerem na czele, miała bronić rejonu Rafajłowej (wieś położona około 20 km na południowy zachód od miejscowości Nadwórna), utrzymać łączność z austriacką 52 DP oraz zabezpieczać linię etapową na Węgry do Teraczköz. W grupie tej znalazły się m.in. następujące bataliony legionowe: I z 3 pp - dowódca kpt. Henryk Odrowąż Minkiewicz; III z 3 pp - dowódca kpt Tadeusz Terlecki; IV z 2 pp - dowódca kpt. B. Roja ${ }^{15}$.

W okresie 27 XI 1914-23 I 1915 oddziały legionowe II Brygady LP pozostawały w rejonie wsi Zielona i Rafajłowa, położonych w malowniczym paśmie górskim Gorganów. Stąd wzięła się nazwa Rzeczpospolita Rafajłowa, przyjęta z czasem dla miejsca stacjonowania następujących jednostek: I i III batalion 3 pp, IV batalion 2 pp, półbateria artylerii (kpt. Mieczysław Jełowicki), pluton jazdy ${ }^{16}$. Legionistom przyszło tam walczyć w wyjątkowo trudnych warunkach, wynikających z górskiego ukształtowania terenu oraz trwającej właśnie ciężkiej zimy. Niezwykle silne mrozy dochodziły do $-30^{\circ} \mathrm{C}$. Nic dziwnego, że Brygadę LP, która zdołała to przetrwać, nazwano „Żelazną”.

W nocy z 23 na 24 I 1915 r. doszło do ataku dwóch batalionów piechoty rosyjskiej na Rafajłową. W obronie polskich pozycji brał udział B. Roja. Mimo

\footnotetext{
14 A. Roliński, A gdy na wojenkę szli ojczyźnie służyć. Pieśni i piosenki żołnierskie z lat 19141918. Antologia, Kraków 1989, s. 124-125.

15 M. Orłowski, Generał Józef Haller 1873-1960, Kraków 2007, s. 80-81.

16 L. Fac, II Brygada Legionów w walkach w Karpatach Wschodnich (6 X 1914-10 I 1915 Marmaros-Sziget-Huszt), [w:] Z walk II Brygady Legionów..., s. 44.
} 
powtarzanych kilka razy zwrotów zaczepnych Rosjanom nie udało się zająć Rafajłowej ${ }^{17}$. Tymczasem dzięki swojej odwadze dowódca IV batalionu 2 pp okrył się sławą wśród żołnierzy legionowych. Jeden z nich tak scharakteryzował Roję: „zawadiacka dusza zagończyka, niepohamowany temperament. (...) Był w tym człowieku młodzieńczy rozmach i ogień, jakaś niespokojna, pełna inicjatywy wola, było przedziwne nieliczenie się z rzeczywistością, wyzywanie własnego szczęścia”"

Po przeniesieniu pułków karpackich na tyły, w dniu 23 II 1915 r. 2 pp LP rozpoczął stacjonowanie w Kołomyi, znanej B. Roi doskonale z okresu służby w ck armii, w 36 pp Obrony Krajowej. To właśnie tam, w związku z napływem ochotników, w marcu 1915 r. dowódca IV batalionu zaproponował Komendzie LP utworzenie 4 pp. W skład nowej jednostki miałby wejść również III batalion 2 pp oraz batalion B. Roi. Decyzje dotyczące zorganizowania 4 pp początkowo zmieniały się jak w kalejdoskopie. Ostatecznie jednak zdecydowano o tworzeniu oddziału na obszarze Królestwa. Tym samym spełniły się szkolne marzenia B. Roi. Jak wspominał po latach, w VI klasie gimnazjum widział siebie jako dowódcę legendarnego 4 pułku spod Ostrołęki, który walczył w powstaniu listopadowym ${ }^{19}$.

Formowanie 4 pp rozpoczęło się wiosną 1915 r. w Rozprzy i Krzyżanowie - na południe od Piotrkowa Trybunalskiego - i trwało od 15 kwietnia do maja 1915 r. Nowa jednostka, wraz z 6 pp, w drugiej połowie 1915 r. miała wejść w skład III Brygady LP. Trzon czwartaków tworzyły jednostki II Brygady LP: II i IV batalion 2 pp oraz II batalion 3 pp. Był to już zaprawiony w boju twardy karpacki żołnierz. Ponadto jednostkę uzupełnili ochotnicy napływający z obszaru Królestwa, odpowiadający na apel Departamentu Wojskowego NKN, mającego siedzibę w Piotrkowie Trybunalskim ${ }^{20}$. Na czele batalionów nowo utworzonego 4 pp stanęli: I - kpt. A. Galica, II - kpt. Franciszek Sikorski, III - kpt. Edward Szerauc. Tymczasem 14 III 1915 r. B. Roja awansował na podpułkownika ${ }^{21}$.

Wiosną 1915 r. z Roją spotkał się dr Jan Hupka, działacz NKN. Obaj znali się jeszcze z czasów przedwojennych z pracy w Towarzystwie Emigracyjnym w Krakowie. W swoim pamiętniku J. Hupka napisał: „Roja okazał się w legionach niesłychanie walecznym oficerem i szybko awansował. Zarzucają mu tylko to, że w jego batalionie są największe straty w poległych i rannych. Opowiadał

17 J. Panaś, Pamiętniki kapelana Legionów Polskich. cz. I. Boje legionowe Karpaty-Bukowina-Besarabia-Królestwo-Wołyń, Lwów 1920, s. 46-49; S. Czerep, dz. cyt., s. 91-94.

18 Cyt. za: J. Konefał, Bój pod Jastkowem, „Tygodnik Powszechny” nr 46, 11 XI 1984, s. 7.

19 CAW, Kolekcja generałów i osobistości - Roja Bolesław, Kwestionariusz z 19 X 1934; B. Roja, Legioniści w Karpatach..., s. 363-365, 369, 371-373.

20 W. Lipiński, Walka zbrojna o niepodległość Polski 1905-1918, Warszawa 1935, s. 89; A. Lewicki, Zarys historii wojennej 4-go Pułku Piechoty Legionów, Warszawa 1929, s. 6; R. Starzyński, Cztery lata wojny w służbie Komendanta. Przeżycia wojenne 1914-1918, Warszawa 1937, s. 115; W. Kozłowski, Artyleria polskich formacji wojskowych podczas I wojny światowej, Łódź 1993, s. 128; W. Milewska, J.T. Nowak, M. Zientara, dz. cyt., s. 71.

21 Mianowania w Legionach, „Wiadomości Polskie” nr 25, 10 IV 1915, Piotrków Trybunalski, s. 5. 
mi ciekawe epizody z walk legionowych i o waleczności swych chłopców. W Polaku każdym, mówi Roja, siedzi żołnierz. Zdaje się z początku, że niejeden to wygodniś, papinek [„,delikacik” - przyp. A.K.], ale poskrobać go tylko, a już cały żołnierz wyłazi. Dziś wieczorem przysłał mi Roja w upominku zdobyczny kindżał czerkieski w srebro oprawny"22.

W dniu 30 V 1915 r., z okazji powstania 4 pp, odbył się bankiet, zorganizowany przez właścicieli majątku w Łochyńsku, koło Rozprzy, gdzie kwaterowało dowództwo jednostki z B. Roją na czele ${ }^{23}$. Jak donosił „Goniec Polowy Legionów”, dzień ten zmienił się w imponującą manifestację narodową. Na stacji kolejowej w Rozprzy na gości czekała kompania honorowa i orkiestra legionowa, która zagrała „Jeszcze Polska nie zginęła”. Warto w tym miejscu wspomnieć, że orkiestra ta powstała dzięki staraniom B. Roi oraz A. Galicy. Podjęli oni starania, aby stworzyć orkiestrę pułkową (wybrano muzyków, zostały zakupione instrumenty; po 2 miesiącach ćwiczeń rozpoczęły się występy publiczne) ${ }^{24}$. Dalszą część uroczystości z okazji utworzenia 4 pp kontynuowano w oddalonym o około $5 \mathrm{~km}$ dworku w Łochyńsku. Tu całe zaproszone towarzystwo zasiadło przy stołach w dwóch pokojach, a pod oknami przygrywała muzyka. Emil Bobrowski nazwał tę uroczystość chrztem pułku. Ówczesny lekarz 4 pp zapisał w swoim pamiętniku: „Chrzest był bardzo zbytkowy: trunki i kanapki (klasa!), zupa, pieczeń, kurczęta, szparagi, lody, tory, wino; najwięcej jednak było polskiego gadania. Zaczął je pułk. Roja nawiązując do tradycji czwartaków i wyraził nadzieję, że nasz pułk nie przyniesie ujmy sławie czwartaków; potem szły toasty na cześć gen. Durskiego, kapitana Zagórskiego, pułk. Roi, pułk. Grzesickiego, kapitana Galicy”25.

W 4 pp większość żołnierzy miała chłopskie pochodzenie. Wśród nich wyróżniali się Podhalanie. Zapewne był to jeden z elementów silnie jednoczących żołnierzy tej jednostki oraz budzących w nich poczucie wspólnoty i solidarności. W 1915 r. na łamach pułkowego czasopisma „Czwartak” podkreślano: „4 pułk piechoty wojsk polskich - toż z chłopów chłopy. A na czele sam Roja. W tej twarzy ogorzałej, w oczach piorunnych i dobrotliwych zarazem, w postaci zamaszystej a serdecznej coś z czasów piastowskich i coś z przewag Kmicicowych tkwi. Lgnie serce żołnierskie do takiego żołnierza. A drugi - Galica! Nasz major i komendant I batalionu - toż to wyraz polskiej rycerskości chłopskiej, z gazdów bowiem wywodzi się ten człek o głębokim sercu i o lwiej na wroga zawziętości. (...) Na żołnierzy, legionistów 4 pułku kto popatrzy, ten od razu pozna - że z tego

22 J. Hupka, Z czasów Wielkiej Wojny. Pamiętnik nie kombatanta, Niwiska 1936, s. 71.

23 A.A. Kozłowska, Góral generałem - Andrzej Galica. Biografia żołnierza, polityka i literata, Łódź 2013, s. 78.

24 J.A. Teslar, Czwarty pułk. Rok działań wojennych 4-go P.P. Legionów Polskich od dnia 10 maja 1915 roku do dnia 10 maja 1916 roku, Lwów 1916, s. 34-35.

25 BZNO, Rkps 12004/I (mf 2189). E. Bobrowski, Pamiętniki 1912-1918, k. 671-673; Legionów pułk czwarty, „Goniec Polowy Legionów” nr 5, 8 VI 1915, Piotrków Trybunalski, s. 1; A. Krasicki, Dziennik z kampanii rosyjskiej 1914-1916, Warszawa 1988, s. 229, 240. 
pułku nowa Polska się rodzi, Polska władcza, o siebie oparta, w swą siłę wierząca, Polska ludowa, bowiem chłopskie dzieci w tym pułku przeważają i chłopskie w nim cnoty"26.

W dniu 15 VII 1915 r. nastąpił wymarsz jednostki na front. Wydarzeniu temu towarzyszyły tłumy mieszkańców Piotrkowa Trybunalskiego, przyglądające się uroczystości. Chwile te uwiecznione zostały na licznych fotografiach, na których widać m.in. pułk ze sztandarem, ofiarowanym wcześniej w Łochyńsku koło Rozprzy przez Ligę Kobiet Pogotowia Wojennego. Na sztandarze barwy amarantowej widniał biały orze ${ }^{27}$. Przed wymarszem na piotrkowskich błoniach została odprawiona msza polowa, poprzedzona krótkim raportem B. Roi złożonym m.in. przed: płk. Wiktorem Grzesickim, ppłk. Władysławem Sikorskim i Janem Dąbskim, reprezentantem NKN. W czasie nabożeństwa grała orkiestra czwartaków. Następnie odbyła się defilada legionistów, na których rzucano „deszcz kwiatów”28.

Barwny opis wymarszu jednostki na front pozostawił Władysław Orkan, Podhalanin, kronikarz czwartaków. Swoją reportażową książkę „Droga czwartaków” zadedykował bohaterskiemu płk. B. Roi. Zaczyna się ona słowami: „Długo pamiętnym dla Piotrkowian zostanie dzień 15 lipca 1915 roku, gdy uformowany właśnie pułk czwarty Legionów wyruszał w pole. A zwłaszcza moment ten, dla wielu przez łzy wzruszenia na zawsze wpamiętniony [sic!], gdy po mszy polowej, na błoniu, wobec jasnego nieba, wobec zebranej licznie publiczności i władz wojskowych, defilowały oddziały pułkowe przy dźwiękach »Marsza czwartaków«. Jechał naprzód pułkownik, o głośnym już - zdobytym w bojach karpackich - imieniu; jechali za nim inni oficerowie pułku, wiodący bataliony swoje; kompanie - szły równo, równo, sprężone, mocne szeregi; a gdy mijali oczy żegnające, salutując, dreszczem przysiężnej powagi uderzały światła ócz żołnierskich i światła wzniesionych szabel o serca ostających"29.

Wymarsz czwartaków na front opisał również w swej powieści Wiesław Jażdzyński: „Pułk stał czworobokiem na piotrkowskim rynku. Ciasno było trochę, bo - trzeba przyznać - ludzi zwaliło się dobre kilka tysięcy. Pierwszy raz obejrzałem sobie dokładnie naszą starszyznę: pułkowników Roję i Galicę, pułkowych lekarzy Bobrowskiego i Kołłątaja, stała karnie w szeregach nasza brać artystyczna, nieźli pacykarze - Czechowski, Wodzinowski, de Laveaux, poeci: Żuławski, Relidzyński, chorąży Orkan, Orlik Broniewski, żurnaliści jak Teslar czy Grzędziński, stali razem z góralami, krakowiakami, nas królewiaków było mało jeszcze, a już dawnych Sybiraków na palcach jednej ręki policzyć”30.

26 Czwartacy, „Czwartak” nr 5, 25 IX 1915, Lublin, s. 1.

27 Więcej na temat sztandarów 4 pp LP: A.A. Kozłowska, 4 Pułk Piechoty Legionów w latach 1915-1939. Ludzie, tradycje i pamiqtki, „Mars”, Warszawa-Londyn 2001, t. 11, s. 81-83.

28 Nowe karty w dziejach Legionów, „Ilustrowany Tygodnik Polski” z. 1, 1 VIII 1915, Kraków, s. 12

29 W. Orkan, Drogq Czwartaków od Ostrowca na Litwę, Kraków 2006, s. 8.

30 W. Jażdżyński, Ogrody naszych matek, Łódź 1984, s. 20-21. Autor był synem ppłk. Stefana Jażdżyńskiego, dowódcy 4 pp (17 V 1921-19 III 1930). Twórczość W. Jażdżyńskiego dotyczyła często tematyki wojennej i partyzanckiej. Pisał także książki dla dzieci. Mieszkał 
Warto w tym miejscu wspomnieć o charakterystycznym elemencie umundurowania czwartaków, jakim były ich czapki, różniące się od noszonych w innych pułkach legionowych. Nazywane były - od nazwisk dowódców pułku - „rojówkami” czy „galicówkami”. Należy je wiązać z osobą B. Roi, który w czasie dowodzenia IV batalionem 2 pp zamówił w Jarosławiu dla swoich podkomendnych zgrabne i foremne - jak sam je określał - rogatywki. Chodziło o ujednolicenie dotychczasowych nakryć głowy, a także o ich estetykę. Równocześnie II i IV batalion 2 pp uchodził za „sokoli” i nie nosił „strzeleckich” maciejówek. Nowy rodzaj czapki odpowiadał Roi i dlatego postanowił przenieść go do tworzonego 4 pp. Na podstawie materiału ikonograficznego można stwierdzić, iż był to rodzaj dosyć wysokiej rogatywki o zmodyfikowanym kształcie ${ }^{31}$.

W dniu 18 VII 1915 r. czwartacy przekroczyli Wisłę, przechodząc po mostach pontonowych, które zostały przerzucone przez rzekę pod Annopolem. Jednostka wkroczyła na ziemię lubelską. Następnego dnia 4 pp połączył się z I Brygadą LP, utworzoną w grudniu 1914 r. Spotkanie to nie było łatwe. Karni żołnierze B. Roi pierwszy raz zetknęli się z „piłsudczykami”. Ci ostatni żartowali sobie z czwartaków, nazywając ich „Austriakami”. Kpili także z ich charakterystycznych czapek „rojówek”. Jak podał Jan Konefał, między żołnierzami dochodziło do żartobliwej wymiany zdań: „»Dlaczego obywatelu diabeł ma tylko dwa rogi, a wy macie aż cztery « - dociekliwie zapytywał żołnierz I Brygady. Nie dający się łatwo zbić z tropu Rojowy żołnierz grzecznie wyjaśniał: »Z diabłem nie mam nic wspólnego, ale nie chcę być podobnym do osła, który wcale nie ma rogów - tak jak wy, obywatelu«"32.

Na przełomie lipca i sierpnia 1915 r. doszło do trwającego 3 dni boju pod Jastkowem, uważanego za faktyczny chrzest bojowy 4 pp. Zakończył się on w nocy z 2 na 3 sierpnia. Straty jednostki były ogromne, wynoszące około 150200 zabitych i rannych. Zdania na ten temat są jednak podzielone. Jak podał W. Orkan, miało to być około 50 zabitych i 270 rannych. W jego opinii nie były to aż tak ogromne straty. Szczególnie, że bój toczył się przez 3 dni. W powszechnej opinii B. Roi zarzucano jednak szafowanie krwią podległych mu żołnierzy. Powodowało to ucieczki legionistów z 4 pp i przechodzenia do innych jednostek, wchodzących w skład I Brygady ${ }^{33}$. Jak wspominał po latach Stefan Benedykt, jeden z czwartaków: „Pułk już w pierwszych godzinach ataku [pod Jastkowem

w Łodzi w domu literata przy al. Kościuszki 98 - Literatura polska. Przewodnik encyklopedyczny, t. I, A-M, Warszawa 1984, t. II, N-Ż, Warszawa 1985.

31 B. Roja, Legioniści w Karpatach..., s. 134-136; Ilustrowana kronika Legionów Polskich 1914-1918, oprac. E. Quirini i S. Librewski, Warszawa 1936, s. 41, fot. 6 i s. 86, fot. 1; H. Wielecki, Polski mundur wojskowy 1918-1939, Warszawa 1995, s. 241-rys. 10 i s. 254. J. Konefał, Jastków 1915. Historia i pamięć, Lublin 2003, s. 21.

33 Tamże, s. 36, 44, 57-59; W. Orkan, Bitwa pod Jastkowem, „Polska Zbrojna” nr 214, 6 VIII 1924, s. 12; J. Kruk-Śmigla, Za wiernq służbę ojczyźnie. Dziennik legionisty I Brygady, oprac. J. Kirszak, Krosno 2004, s. 37-38. Autor w ciekawy sposób skomentował ogromne straty poniesione przez 4 pp w boju pod Jastkowem: „Szkoda ich, gdyż winę ponoszą tylko ich nieudolni oficerowie. Gdyby oficerów mieli naszych [sam służył w 1 pp - przyp. A.K.] zupełnie inaczej by się bili. Można też wytłumaczyć ten fakt, że wszyscy chcą uciekać do I-szej Brygady. Uciekinierów jest też bardzo dużo”. 
- przyp. A.K.], prowadzony przez płk. Bolesława Roję miał straty duże, wprost olbrzymie w stosunku do możliwości uzupełnień i szczupłości naszych kadr. I wtedy interweniował Komendant, który nigdy nie narażał swych żołnierzy niepotrzebnie, dla fasonu czy jak to nazwać"34. Rzeczywiście, po południu 31 VII 1915 r. gen. K. Trzaska-Durski, komendant LP, podporządkował 4 pp Józefowi Piłsudskiemu. Ten starał się wpłynąć na B. Roję, aby oszczędzał swoich żołnierzy. Sprawa stała się jednak głośna i obawiano się jej oddźwięku w społeczeństwie. Służący w czwartakach January Grzędziński wspominał po latach, że informacji o stratach poniesionych pod Jastkowem nie podawano do publicznej wiadomości i pomniejszano je „wbrew austriackiej modzie”, aby nie straszyć opinii publicznej ${ }^{35}$.

Sprawa nadmiernych strat pod Jastkowem ciągnęła się za B. Roją latami. W swojej książce „Legendy i fakty” ówczesny generał odniósł się do tej kwestii: „Pod Jastkowem, wiadome, kazano 4. pułkowi, na dobry jego początek, atakować trudne, na wzgórzach odrutowane pozycje. Miał 4 pułk pierwszego rozkazu tego nie wykonać, kiedy to usuwaliśmy, bądź co bądź, jednego z zaborców z ziem polskich? Straty być musiały. Zresztą pomnożono je, spopularyzowano"36.

Bez wątpienia jednak reżim i dyscyplina panująca w 4 pp za sprawą B. Roi budziły kontrowersje i emocje. Przyczyniało się to do wspomnianych dezercji z 4 pp. Jak podał w swojej relacji Gotlib (Gottlieb) Froim, jeden z czwartaków, miał on zostać uderzony przez dowódcę w twarz. Z tego powodu uciekł do I Brygady $\mathrm{LP}^{37}$. Jednak B. Roja uważał surowe traktowanie podkomendnych za element niezbędny do utrzymania dyscypliny. Zresztą zarzuty dotyczące szafowania życiem żołnierzy pojawiają się dosyć często. Jako przykłady można podać generałów Władysława Andersa i Stanisława Maczka. Dowódcę 1 Dywizji Pancernej żołnierze określali czasem nawet mianem „rzeźnik”38.

Wracając do postaci B. Roi, należy podkreślić ogromną odwagę tego człowieka. Takim postrzegali go współcześni. Jan Dunin Brzeziński z 2 pułku ułanów LP wspominał, jak B. Roja osobiście sprawdzał pozycje obsadzone nie tylko przez jego podkomendnych, lecz także odcinki podlegające innym dowódcom. Stwarzał w ten sposób niepotrzebne zagrożenie dla swojego życia. „Był to jednak zwyczaj jego, pomimo że narażał żołnierzy i życia ludzkiego nie żałował, sam świecił nadzwyczajnym przykładem i odwagą, i siebie nigdy nie oszczędzał”39.

34 S. Benedykt, Legiony, to żołnierska nuta, „Wiadomości” nr 32, 9 VIII 1964, Londyn, s. 1.

35 A. J. Cieślikowska, O człowieku, który się nie zgadzał. Biografia pułkownika Januarego Grzędzińskiego 1891-1975, Warszawa 2009, s. 67; W. Jaskulski, Generał brygady Józef Olszyna-Wilczyński (1890-1939), Włocławek 2013, s. 58.

36 B. Roja, Legendy i fakty, Warszawa 1931, s. 37.

37 M. Gałęzowski, Na wzór Berka Joselewicza. Żołnierze i oficerowie pochodzenia żydowskiego w Legionach Polskich, Warszawa 2010, s. 276.

38 Byliśmy czarnymi diabłami. Wywiad z ppor. Piotrem Juralewiczem, http://www.polska1918-89.pl/pdf/bylismy-czarnymi-diablami,1564.pdf [dostęp: 31 I 2019].

39 J. Dunin-Brzeziński, Rotmistrz Legionów Polskich. Wspomnienia z lat 1914-1919, Pruszków 2003, s. 134. 
Tymczasem po boju pod Jastkowem B. Roja pomaszerował wraz z 4 pp przez Krasienin (wieś położona około 15 km na północny zachód od Lublina) do Wólki Krasienińskiej. W dniach 5-7 sierpnia prowadzono walki w rejonie: Siedliska-Bratnik, Kozłówka, Kamionka. W tym czasie Niemcy zajęli Warszawę. Wiadomość o tym wydarzeniu dotarła do legionistów, wywołując mieszane uczucia. Oto bowiem kolejny raz stolica znalazła się w obcych rękach. Równocześnie jednak skończyło się znienawidzone carskie panowanie. Z tej okazji dowództwo 4 pp zorganizowało bankiet dla oficerów. Panowała swobodna atmosfera, wiwatowano przy koniaku i winie. Dowódca czwartaków przyjmował swoich oficerów na dziedzińcu zajmowanego budynku, pozostając w częściowym negliżu - bez kurtki mundurowej. Dla uczczenia tego dnia wszyscy robili sobie pamiątkowe fotografie z płk. B. Roją, który konsekwentnie bluzy nie założył ${ }^{40}$.

Tymczasem 4 pp otrzymał rozkaz marszu do Kołków i zajęcia linii Janówka - Kolonia Czebenie (powiat Łuck) nad Styrem. To właśnie do Czebeni w dniu 21 IX 1915 r., wraz z 5 pp, przybył J. Piłsudski. Gość został zaproszony na obiad, który zjadł w towarzystwie m.in.: mjr. Leona Berbeckiego - dowódcy pułku, kpt. Tadeusza Piskora, B. Roi, A. Galicy i dr. E. Bobrowskiego. Lekarz czwartaków wspominał, że popijano wówczas doskonałą nalewkę wiśniową, a starym tokajem wznoszono toasty za pomyślne współdziałanie 4 i $5 \mathrm{pp}^{41}$.

Należy wspomnieć, że nieco wcześniej, w połowie września 1915 r., B. Roja otrzymał austriackie odznaczenie - Wojskowy Krzyż Zasługi (Militär-Verdienstkreuz ${ }^{42}$. Natomiast z dniem 25 IX 1915 r. awansował do stopnia pułkownika ${ }^{43}$. W listopadzie 1915 r. 4 pp został odwołany spod dowództwa J. Piłsudskiego. W dniu 24 XI 1915 r. A. Galica przejął czasowo obowiązki płk. B. Roi, który w tym czasie zastąpił na czas nieobecności płk. W. Grzesickiego, dowódcę III Brygady LP ${ }^{44}$.

Dowódca czwartaków wysoko oceniał wartość bojową swoich podkomendnych w czasie walk na Wołyniu. Na początku grudnia 1915 r. skierował do Komendy LP wnioski awansowe dla dowódców wszystkich batalionów 4 pp (dla mjr. A. Galicy - na podpułkownika, dla kapitanów E. Szerauca i F. Sikorskiego - na majorów). Zdaniem B. Roi, zasługiwali oni na wyższy stopień oficerski „za służbę na froncie pełną dodatnich wyników, za umiejętne prowadzenie oddziałów

$\overline{40}$ BZNO, Rkps 12926/II (mf 2435). K. Baczyński, Odpis pamiętnika ppłk. Karola Baczyńskiego z przeżyć jego po powierzeniu mu komendy punktu zbornego rekrutów dla LP w Jastkowie, od dnia 5 VIII 1915 r., k. 2-3.

41 E. Bobrowski, Urywki z pamiętnika, „Czwartak” nr 5-6, III 1938, Warszawa, s. 4-5; W. Jędrzejewicz, J. Cisek, Kalendarium życia Józefa Piłsudskiego, t. I, 1867-1916, Kraków-Łomianki 2006, s. 436; J.E. Teslar, dz. cyt., s. 19.

42 A. Krasicki, dz. cyt., s. 338; V. Měřička, Orden und Auszeichnungen, Praga 1969, s. 37-38, il. 73.

43 Lista starszeństwa..., Warszawa 1917, s. 2.

44 W. Jędrzejewicz, Kronika życia Józefa Piłsudskiego 1867-1935, Londyn 1986, t. I, 18671920, s. 313-314; J.A. Teslar, dz. cyt., s. 21-22; A.A. Kozłowska, Góral..., s. 85. 
w guberni lubelskiej, pod Kowlem, nad Stochodem i pod Koszyszczami i za karność utrzymywaną w swoich oddziałach”45. I chociaż wówczas jeszcze wspomniani oficerowie awansów nie otrzymali, to wniosek płk. B. Roi świadczył, jak wysoko cenił ich ten wymagający i surowy dowódca.

W dniu 9 XII 1915 r. 4 pp przeniesiony został pod Optową nad Styrem, gdzie jednostka spędziła kilka następnych miesięcy. Powstał tu obóz legionowy. To właśnie pod Optową 26 II 1916 r. B. Roja ponownie został ranny w rękę. Następnego dnia odwiedził go gen. mjr Stanisław Puchalski - komendant LP, kpt Włodzimierz Ostoja Zagórski - szef sztabu Komendy LP oraz por. August Krasicki, adiutant wspomnianego komendanta. Ten ostatni zapisał w swoim dzienniku: „Pułkownika Roję zastaliśmy w łóżku z obandażowaną prawą ręką na temblaku. Przedwczoraj poszedł on $\mathrm{z}$ patrolem przed front rosyjski, gdy byli niedaleko okopów rosyjskich płk Roja z jednym żołnierzem wysunęli się naprzód, idąc, natknęli się na dwa psy czarne, które pędem pobiegły ku okopom rosyjskim. Jak się pokazało były to psy wojskowe, które w ten sposób zaalarmowały placówkę, gdyż niebawem na 50 kroków wypaliła na nich salwa karabinowa. Żołnierz dostał kulę w głowę i brzuch i padł na miejscu, płk Roja w prawą rękę, poniżej łokcia, kość i ścięgna ma nienaruszone, ale kula wyrwała kawałek ciała z ręki. Szczęśliwie z resztą patrolu wycofał się, silnie krwawiąc” ${ }^{46}$. Tym razem rana była tak poważna, że B. Roja musiał się udać na urlop zdrowotny. W okresie rekonwalescencji dowódcy 4 pp zastępował A. Galica.

Przed Wielkanocą 1916 r. obozowisku legionowemu pod Optową nadano nowy wiosenny wygląd. Ponadto, w związku z powrotem do pułku jego dowódcy płk. B. Roi po rekonwalescencji, mjr A. Galica przygotował coś specjalnego. Uporządkowano las, w którym leżało obozowisko czwartaków oraz ustawiono bramę z wielkim napisem „Rojowe Osiedle”. Oczywiście, na cześć dowódcy jednostki ${ }^{47}$.

Wiosną 1916 r. w 4 pp zorganizowano święto związane z pierwszą rocznicą powstania jednostki. Uroczystości odbyły się w Rojowym Osiedlu w dniu 28 maja. Rozpoczęły się od życzeń złożonych przez mjr. A. Galicę na ręce dowódcy pułku, który otrzymał również wspaniały prezent w postaci srebrnej szabli z ryngrafem przedstawiającym Matkę Boską oraz napisem: Pułkownikowi Roi - Czwartacy. „Pułkowniku! - brzmiało krótkie, żołnierskie przemówienie majora - Oficerowie 4. pp. Legionów stawili się, aby Ci w dniu rocznicy pułkowej złożyć najserdeczniejsze życzenia. Że pułk czwarty zdobył sobie dobrą sławę, jaką się cieszy, to Twoja w pierwszym rzędzie zasługa. Prowadziłeś nas z bitwy do bitwy, a zawsze spokojnie, mężnie i zwycięski. Wymagałeś karności bezwzględnej,

45 CAW, Komenda LP I.120.1, t. 266. Wniosek o awanse skierowany do Komendy LP w Wołczecku przez płk. B. Roję z 4 XII 1915 r. Na rewersie dokumentu adnotacja płk. W. Grzesickiego, że z awansami tymi należy się jeszcze wstrzymać.

46 A. Krasicki, dz. cyt., s. 415-416; Lista strat Legionów Polskich (wyd. przez Centralny Oddział Ewidencyjno-Werbunkowy Departamentu Wojskowego NKN), 1 IV 1916, Piotrków Trybunalski, s. 16.

47 K. Nowina-Konopka, Wspomnienia wojenne kapelana II Brygady Legionów Polskich, oprac. J. Humeński, Kraków 1993, s. 64. 
a mimo to potrafiłeś pozyskać bezwzględnie i serca nasze. $\mathrm{W}$ dowód Twych zalet rycerskich oficerowie 4. pp. Leg. Pol. składają Ci szablę w ofierze"48.

Na święto czwartaków został zaproszony J. Piłsudski, któremu B. Roja wręczył pierwszy, prototypowy egzemplarz odznaki pamiątkowej 4 pp. Przybyły także delegacje pozostałych pułków legionowych. Wśród licznych gości pojawili się m.in.: gen. mjr S. Puchalski, komendant LP, ppłk W. Sikorski, gen. mjr. W. Grzesicki czy biskup Władysław Bandurski. Ten ostatni przyjechał z Wiednia. Zorganizowano zawody sportowe oraz uroczysty poczęstunek. Goście usadowieni zostali przy długich stołach, na których znalazły się kanapki, wódka, kilka beczek ciemnego piwa, a nawet ciasta ${ }^{49}$.

W czasie święta doszło jednak do pewnego incydentu. Dowódca 4 pp w obecności przybyłych gości wygłosił przemówienie, w którym zadeklarował się jako zdecydowany piłsudczyk. Nawiązał do okresu wspólnych walk czwartaków z I Brygadą i braterstwa broni, jakie się wówczas nawiązało. Jak podkreślił B. Roja, komendant J. Piłsudski „przykuwał” do siebie żołnierzy już nie tylko swoim imieniem, ale swoim jasnym, celowym postępowaniem. Wkrótce został za to przedstawiony przez gen. W. Grzesickiego do raportu Komendzie LP ${ }^{50}$.

Wspomniana wcześniej odznaka pamiątkowa czwartaków miała kształt swastyki i stała się znakiem rozpoznawczym tej jednostki. Przypuszcza się, że pojawiła się w 4 pp za sprawą górala A. Galicy. Swastyka pochodziła ze starożytnych Indii, gdzie oznaczała szczęście oraz pomyślną wróżbę. Prasłowianie widzieli w niej również symbol słońca i ognia. Takie znaczenie przypisywali jej również górale. Po latach A. Galica wspominał: „Płomienie swastyki zwrócone w prawą stronę tworzą skrzyżowane dwa S, co oznacza szczęście. (...) Swastyka szczęśliwa przedstawia także cztery czwórki. Z tego powodu zaproponowałem ją płk. Roi, jako znak pułkowy 4 pp”51. Końcowy projekt odznaki miał przygotować znakomity artysta rzeźbiarz Jan Raszka. Wspomniane czwórki utworzyły rodzaj krzyża. Pośrodku, w kwadracie umieszczony został wizerunek orła otoczony napisem: ROK WOJNY ZASŁUGA 1915-1916 4 PP. Odznaka miała być pamiątką „za szare tygodnie zaparcia się i wytrwania wśród trudnych i nieprzyjaznych warunków”52.

48 T.S. Grabowski, Święto Legionów na Polesiu. Obchód rocznicy Czwartego pułku, „Wiadomości Polskie” nr 81, 18 VI 1916, Piotrków Trybunalski, s. 4.

49 Fotografia przedstawiająca święto pułkowe 4 pp, 28 V 1916 - w posiadaniu autorki; W. Jędrzejewicz, dz. cyt., s. 325; J. Kruk-Śmigla, dz. cyt., s. 70, 73-75; K. Nowina-Konopka, dz. cyt., s. 64-65.

50 Przemówienie pułk. Bolesława Jerzego Roi, na uroczystości 4-go pp. Legionów Polskich w dniu 28. maja 1916, „Wiadomości Polskie” nr 81, 18 VI 1916, Piotrków Trybunalski, s. 8-9; R. Starzyński, dz. cyt., s. 227.

51 BZNO, Rkps 13868/I (mf 3717). Z życia strzelców podhalańskich. Szkice historyczne napisał Andrzej Galica, Nazwa, k. 27.

52 H. Wielecki, R. Sieradzki, Wojsko Polskie 1921-1939. Odznaki pamiqtkowe piechoty, Warszawa 1991, s. 31; W. Milewska, M. Zientara, Sztuka Legionów Polskich i jej twórcy 19141918, Kraków 1999, s. 235-236; Z. Sawicki, A. Wielechowski, Odznaki Wojska Polskiego 1918-1945. Katalog zbioru falerystycznego. Wojsko Polskie 1918-1939. Polskie Siły 
O tym, jak ważna była odznaka 4 pp dla jej żołnierzy, świadczy wiersz pt. „W trzecią rocznicę święta "Swastyki«", który powstał w 1919 r. Jego autor - A. Bienek (imienia nie ustalono) - tak pisał o walce legendarnej jednostki i o sile, którą dawał im tytułowy symbol:

\author{
„(...) Zapał do czynu owionął nas, \\ Kiedy kraj jęczał w sztuki rozdarty; \\ $\mathrm{O}$ równe prawa dla biednych mas \\ $\mathrm{Z}$ »Swastyki« godłem walczył pułk czwarty. \\ Kiedy w okopach sypał grad kul \\ I żołnierz ginął z śmiertelną raną, \\ »Swastyki« krzyżyk zmniejszał mu ból \\ I tylko ten krzyż z trupem grzebano. \\ „Swastyko « święta! przyjm naszą cześć! \\ Niech nam pomaga wielka moc Twoja! \\ Na pole chwały w Twym znaku wieść \\ Będzie pułk czwarty Generał Roja”53.
}

W lutym 1916 r. dotychczasowego Komendanta LP gen. por. K. Trzaskę-Durskiego zastąpił gen. mjr S. Puchalski. Wkrótce doszło także do utworzenia tzw. Rady Pułkowników, nieformalnego organu doradczego przy Komendzie LP. Trudno ustalić, kto był faktycznym inicjatorem jego powstania. Jak wspominał po latach B. Roja: „Dla szerszego, solidarnego, przeciwstawienia się, położenia tam i kresu wpływom »ugodowców «, N.K.N. i komend zaborców na legionistów w kierunku ugodowym, organizuję wówczas w 4. pułku moim z dowódców wszystkich pułków i bryg. leg. »Radę pułkowników«. Wobec bowiem dalszych widocznych zamierzeń i intensywnych poczynań zaborców przeistoczenia Legionów w formację bez aspiracji niepodległościowych, sytuacja polityczna staje się dla nas w Legionach politycznie, narodowo z dnia na dzień trudniejszą"54.

Faktycznie, wydaje się jednak, że to właśnie B. Roja odegrał zasadniczą rolę w powołaniu rady do życia Rady Pułkowników. Doprowadził on do opracowania jednobrzmiącego listu z 4 II 1916 r., skierowanego do dowódców jednostek I Brygady. Poza B. Roją dokument ten podpisali: mjr A. Galica (w imieniu ppłk. Mieczysława Norwida-Neugebauera, dowódcy 6 pp, który w tym czasie przebywał na urlopie), ppłk M. Żegota-Januszajtis i ppłk H. Odrowąż Minkiewicz. W liście tym zwracano uwagę na konieczność podjęcia wspólnych działań na rzecz uzdrowienia sytuacji panującej w $L P^{55}$.

Apel spotkał się z pozytywnym odzewem. Już 14 lutego doszło do pierwszego oficjalnego spotkania reprezentantów pułków legionowych w Rojowym

Zbrojne na Zachodzie, Warszawa 2007, s. 30-31. Oficjalnie odznaka została wprowadzona Rozkazem Dziennym Dowódcy 4 pp nr 238 z 14 IX 1916.

53 W. Jeziorski, Śpiewy i śpiewki żołnierskie 1914-1921, Cieszyn b.r.w., s. 51-52.

54 B. Roja, Legendy..., s. 37.

55 T. Wawrzyński, Rada Pułkowników w Legionach Polskich (luty-wrzesień 1916), „Studia i Materiały do Historii Wojskowości” 1988, t. XXX, s. 266-267. 
Osiedlu. Pojawili się na nim: ppłk E. Śmigły-Rydz - 1 pp, ppłk M. Żegota-Januszajtis - 2 pp, ppłk H. Odrowąż Minkiewicz - 3 pp, mjr L. Berbecki - 5 pp, mjr Michał Żymierski - 7 pp, mjr Ottokar Brzoza-Brzezina - 1 pułk artylerii, także mjr A. Galica, który nadal reprezentował dowódcę 6 pp. Zgromadzeni oficerowie starali się wypracować wspólną dla wszystkich trzech brygad postawę wobec Komendy LP. Podporządkowanie się Komendzie LP uznano za możliwe jedynie w sferze wojskowej, ale nie politycznej. Same LP miały być formacją przejściową, stanowiącą pewien etap na drodze do utworzenia armii polskiej. Za szkodliwą uznano działalność kpt. W. Ostoi Zagórskiego, szefa sztabu Komendy LP. Uznano również za niedopuszczalne samowolne przenoszenie się żołnierzy do innego pułku. W trakcie dyskusji dochodziło jednak do pewnych sporów. Zarówno B. Roja - oddany J. Piłsudskiemu - jak i A. Galica całkowicie popierali tezy wypowiadane przez dowódców. Tymczasem oficerowie z II Brygady pozostawali w pewnej opozycji ${ }^{56}$. Drugie zebranie Rady Pułkowników zorganizowano w tym samym miejscu, dnia 23 III 1916 r. Tematem spotkania było wówczas umundurowanie i dystynkcje legionowe. Przedstawiono projekty przygotowane przez ppłk. E. Śmigłego-Rydza, płk. M. Żegotę-Januszajtisa oraz mjr. A. Galicę. Ostatecznie jednogłośnie przyjęto propozycję oznak stopni podoficerskich i oficerskich, jakie miały zostać wprowadzone w $\mathrm{LP}^{57}$.

Rada Pułkowników wznowiła swoją działalność w II połowie 1916 r. W końcu czerwca 1916 r. doszło bowiem do konfliktu z Komendą LP, którego przedmiotem stały się oznaki legionowe. Żołnierze 4 i 6 pp, czyli III Brygady, założyli na mundury oznaki stopni wojskowych obowiązujące w I Brygadzie. Jednak gen. S. Puchalski nakazał przywrócenie dotychczasowych oznak. Przeciwstawił się temu 6 pp. W tej sytuacji w dniu 1 lipca zorganizowano zebranie Rady Pułkowników, na którym zadecydowano o natychmiastowym zdjęciu wszelkich oznak przez wszystkie oddziały LP oraz nałożeniu czerwonych oznak I Brygady (wężyki lub poziome paski z tasiemki naszyte na kołnierzu) przez wszystkie jednostki legionowe. Miało to nastąpić dnia 5 VII 1916 r. Domagano się również przydzielenia do Komendy LP oficerów legionowych. O panującym napięciu świadczy fakt, że 2 dni później Rada Pułkowników cofnęła decyzję o nałożeniu oznak I Brygady. W akcie międzypułkowej solidarności planowano natomiast zdjęcie wszelkich oznak. W obradach, które miały miejsce 1 i 3 VII 1916 r., brał udział B. Roja oraz m.in.: J. Haller, A. Galica, E. Śmigły-Rydz, płk Kazimierz Sosnkowski, L. Berbecki czy mjr Albin Satyr-Fleszar ${ }^{58}$. Narastający konflikt został jednak przerwany na jakiś czas przez ofensywę gen. Aleksieja Brusiłowa. W jej wyniku dniach 4-6 VII 1916 r. doszło pod Kostiuchnówką do największej bitwy legionowej. Uczestniczyły w niej jednostki I i III Brygady LP, w tym 4 pp,

56 W. Lipiński, Szlakiem I Brygady. Dziennik żołnierski, Warszawa 1927, s. 190-191; W. Suleja, Pierwsze posiedzenie Rady Pułkowników w relacji Leona Berbeckiego, „Niepodległość”, t. XLVI (t. XXVI), Nowy Jork-Londyn-Wrocław 1993, s. 91-104.

57 M. Klimecki, K. Filipow, Legiony to... Szkice z dziejów Legionów Polskich, Białystok 1998, s. 116-117.

58 APKr, NKN, sygn. 430 (mf 100628): Uchwała Pułkowników na zebraniu z dnia 1 VII 1916 r., k. 127; Uchwały Pułkowników z dnia 3 VII 1916, k. 128-129. 
pozostający pod dowództwem płk. B. Roi. W bitwie poległo, zostało rannych lub zaginęło około 2 tys. polskich żołnierzy. Potwierdziła ona jednak wielką wartość bojową jednostek legionowych. Dzięki ich poświęceniu, pod Kostiuchnówką nie doszło do przełamania frontu. Armia austro-węgierska musiała się wycofać, jednak wyczerpana strona rosyjska przez długi czas nie była w stanie podjąć kolejnej poważnej ofensywy ${ }^{59}$.

$\mathrm{Z}$ dnia 30 sierpnia tegoż roku pochodził memoriał skierowany do NKN, podpisany przez J. Piłsudskiego i J. Hallera oraz ppłk. B. Roję i płk. K. Sosnkowskiego. Domagano się w nim m. in.: podkreślania wobec rządu austriackiego, że LP są zaczątkiem polskiego wojska i walczą o niepodległość państwa polskiego; współpracy ze strony Komendy Legionów; likwidacji Departamentu Wojskowego NKN; wstrzymania werbunku do LP na dotychczasowych zasadach. Memoriał spotkał się żywą reakcją NKN i Komendy Legionów, a gen. S. Puchalski uznał dokument za przejaw braku dyscypliny wojskowej i warcholstwa ${ }^{60}$.

W dniu 29 IX 1916 r. AOK udzieliło J. Piłsudskiemu dymisji z LP. Wywołało to ogromne zaniepokojenie wśród społeczeństwa i legionistów, przed którymi pojawił się dylemat, jak zachować się w zaistniałej sytuacji. Wspomniany już J. Grzędziński, zapisał w swoich pamiętnikach: „Przyjechał do mnie Kazik Stamirowski - beliniak [wówczas chorąży 1 pułku ułanów LP - przyp. A.K.]. Zaczynamy się kontaktować. Co robić? Beliniacy proponują gremialne podanie się do dymisji. Argumentacja wydaje się prosta: »jestem ochotnikiem, lecz już nie mam ochoty«. Mylą się jednak ci, co uważają, że rozporządzamy nadal wolną wolą. Niestety - nie. (...) Złożyliśmy przysięgę na cały czas wojny. A wojna się nie skończyła. (...) Z Stamirowskim poszliśmy do Roi. Roja uprościł sprawę. Jego zdaniem nie podtrzymać Piłsudskiego, choć o to sam nie prosi, to katastrofa Legionów. Nigdy nie będziemy stadem! Podajemy się do dymisji. Roja postara się dowiedzieć, jakie podał motywy komendant i je powtórzymy. A jeśli się nie dowie, to bez motywów. Stamirowski wyraził zgodę za beliniaków, za nas zgodził się Roja. Przenieśli sprawę Rady Pułkowników, którą zwołano by uchwalić to: legioniści wszystkich formacji podają się do dymisji. (...) Ale co z nami, co się z nami stanie?”61. Ostatecznie, wówczas jeszcze B. Roja pozostał w szeregach LP. Jak się okazało, miał je opuścić rok później.

Tymczasem 5 XI 1916 r. cesarze Niemiec i Austro-Węgier ogłosili akt stanowiący zapowiedź utworzenia ograniczonego terytorialnie, ale jednak samodzielnego Królestwa Polskiego. Dowódca 4 pp przebywał wówczas w Krakowie. W dniu 7 listopada był obecny na przyjęciu zorganizowanym dla oficerów legionowych w Hotelu Saskim. Nie zabrakło na nim również J. Piłsudskiego. Następnego dnia w Krakowie odbyły się huczne uroczystości z powodu wydania wspomnianego aktu. Rozpoczęła je feta przed ratuszem miejskim. Po niej pochód

59 M. Wrzosek, Polski czyn zbrojny podczas pierwszej wojny światowej 1914-1918, Warszawa 1990, s. 239-243.

60 Biblioteka Śląska - Katowice, Druki ulotne, sygn. U.R.1350. Do Naczelnego Komitetu Narodowego, 30 VIII 1916; I. Daszyński, Pamiętniki, t. II, Kraków 1926, s. 239; W. Milewska, J.T. Nowak, M. Zientara, dz. cyt., s. 200-201.

61 Cyt. za: A.J. Cieślikowska, dz. cyt., s. 72; Lista starszeństwa..., s. 43. 
złożony z legionistów, przedstawicieli władz miasta, organizacji społecznych oraz tłumów mieszkańców Krakowa przeszedł do katedry wawelskiej. Za grupą weteranów z powstania styczniowego szedł J. Piłsudski, B. Roja, K. Sosnkowski i pozostali oficerowie legionowi. Po mszy świętej odprawionej na Wawelu B. Roja uczestniczył w uroczystym posiedzeniu rady miasta, na którym przemówienie wygłosił dr Juliusz Leo, prezydent Krakowa ${ }^{62}$.

Po ogłoszeniu aktu 5 listopada LP wkroczyły do Królestwa. Były to następujące jednostki II Brygady: 3 i 4 pp, 2 pułk ułanów, oddziały karabinów maszynowych, saperów i artylerii. Rozmieszczono je w Warszawie oraz Zegrzu. Początek 1917 r. przyniósł B. Roi kolejne odznaczenie austriackie. Jak podano w „Dzienniku Rozporządzeń Obrony Krajowej” nr 25 z 10 II 1917 r., pułkownik otrzymał Order Żelazny Korony (Österreichisch-Kaiserlicher Orden der Eisernen Krone) klasy III z dekoracją wojenną ${ }^{63}$.

Należy wspomnieć, że w okresie służby w LP płk B. Roja związany był z sądownictwem wojskowym. W dniu 19 V 1917 r. ogłoszono wyniki wyborów do sądu honorowego dla oficerów sztabowych. Funkcję przewodniczącego objął płk J. Haller. W składzie sądu odwoławczego znalazł się płk E. Śmigły-Rydz (przewodniczący) oraz ppłk dr Wojciech Rogalski i ppłk A. Galica (członkowie). Mieli ich zastępować: płk B. Roja, ppłk M. Norwid-Neugebauer i mjr Władysław Belina-Prażmowski ${ }^{64}$.

W dniu 18 VI 1917 r. B. Roja został dowódcą III Brygady LP. Zastąpił na tym stanowisku płk. Z. Zielińskiego. W lipcu tego roku brał udział w dramatycznych wydarzeniach związanych z tzw. kryzysem przysięgowym. Z racji pełnionej funkcji był obecny podczas składania przysięgi, 13 VII 1917 r., przez 5 pp LP. Roman Starzyński (brat Stefana), żołnierz tego pułku, wspominał, że B. Roja przyjechał na tę uroczystość wraz z inż. Antonim Kaczorowskim, delegatem Tymczasowej Rady Stanu. Dowódca III Brygady, zwracając się do ustawionych w czworobok żołnierzy, pozostawił kwestie złożenia przysięgi na wierność i zachowanie braterstwa broni z wojskami Austro-Węgier i Niemiec ich sercom i sumieniom. Następnie wygłosił przemowę A. Kaczorowski, który odczytał także treść przysięgi. Cały pułk odmówił jej złożenia, ku nieskrywanemu zadowoleniu mjr. Mieczysława Rysia-Trojanowskiego, dowódcy jednostki. Na polecenie B. Roi odbyła się defilada, po której szeregowcy ze śpiewem odmaszerowali

62 $\quad$ MTN w Łodzi, Dział Zbiorów - Archiwalia, sygn. A-8778. Karta pocztowa z autografami oficerów zgromadzonych na przyjęciu w Hotelu Saskim w Krakowie, 7 XI 1916; Obchód w Krakowie, „Czas” nr 565, 8 XI 1916, wydanie wieczorne, s. 1-2.

63 APŁ, Główny Urząd Zaciągu do Wojska Polskiego, t. 2. Rozkaz Departamentu Wojskowego NKN nr 31 z 16 II 1917 (Piotrków Trybunalski), zawierający wyjątek z odprawy Komendy LP, k. 82. Order Żelaznej Korony (Österreichisch-Kaiserlicher Orden der Eisernen Krone) klasy III miał formę dwugłowego orła wspartego szponami na koronie i zawieszonego na trójkątnej wstążce. Na piersi orła, na awersie, umieszczono literę „F”. Na rewersie widniała data: „1815”. Dekorację wojenną tworzyły dwie gałązki laurowe obejmujące półkoliście boki orła - V. Měřička, dz. cyt., tabl. 73 i 93.

64 APŁ, Główny Urząd Zaciągu do Wojska Polskiego, t. 6: Rozkaz Komendy LP nr 122 z 19 V 1917 podpisany przez płk. Z. Zielińskiego, k. 70; Rozkaz Komendy LP nr 128 z 4 VI 1917 podpisany przez płk. Z. Zielińskiego, k. 74. 
do koszar. Wspomniany R. Starzyński tak opisywał dalszy ciąg wydarzeń: „Oficerowie tymczasem wznoszą okrzyki na cześć płk. Roi. Chwytają go na ręce i na ramionach niosą do kasyna oficerskiego 5. p.p. Żołnierze kompanii, które odszedłszy do koszar rozeszły się, tłumnie otaczają oficerów bez końca wznoszą okrzyki: »Niech żyje płk Roja«. »Niech żyje nasz komendant mjr Trojanowski«"65.

W wyniku wydarzeń związanych z kryzysem przysięgowym, w dniu 3 VIII 1917 r. płk B. Roja został zwolniony z LP i skierowany do Grazu w Austrii ${ }^{66}$. Podobnie jak inni oficerowie legionowi, którzy znaleźli się w szeregach ck armii, został zdegradowany do stopnia podporucznika i nie mógł nosić munduru legionowego. W Grazu rozpoczął służbę w 3 pułku strzelców tyrolskich. Równocześnie - po objęciu urzędowania przez Radę Regencyjną w Warszawie (27 X 1917 r.) - wzywał żołnierzy służących w armii austriackiej do powrotu „do polskich szeregów”. Spotkał się jednak z krytyką środowiska legionowego, które uważało za niedopuszczalny powrót bez zwolnienia z obozów internowania osób przetrzymywanych w Beniaminowie czy Szczypiornie ${ }^{67}$.

Dzięki interwencji posła Hermana Liebermana oraz Włodzimierza Przerwy-Tetmajera B. Roja opuścił szeregi ck armii i wiosną 1918 r. znalazł się w Krakowie. Wraz z prof. Władysławem Konopczyńskim, historykiem i inż. Ludwikiem Regieciem w grudniu tegoż roku założył Żeglugę Polską - Spółkę Akcyjną (miała ona siedzibę na Rynku Głównym 19). Równocześnie pułkownik zaczął nawiązywać kontakty ze swoimi byłymi podkomendnymi z 4 pp LP w celu konspiracyjnego utworzenia jednostki wojskowej, która miałaby wziąć udział w przejmowaniu w Krakowie władzy przez Polaków. Ostatecznie jednak decydująca rolę w rozbrajaniu garnizonu austriackiego w dniu 31 X 1918 r. odegrał por. Antoni Stawarz, ówczesny oficer austriackiego 9 pp. Podporządkował się on jednak B. Roi. Ten ostatni został mianowany przez Polską Komisję Likwidacyjną komendantem krakowskiego okręgu wojskowego ${ }^{68}$. Wydarzenia te upamiętnia tablica pamiątkowa odsłonięta w 1988 r. na zewnątrz wieży ratuszowej na Rynku Głównym w Krakowie. Jest na niej wymieniony właśnie B. Roja.

Wydarzenia związane z odzyskaniem przez Polskę niepodległości znalazły się na kartach pamiętnika księżnej Marii Lubomirskiej. Żona Zdzisława Lubomirskiego, członka Rady Regencyjnej, dała przy tej okazji ciekawą charakterystykę B. Roi. Pod datą 1 XI 1918 r. księżna zanotowała: „Wypadek korzystny niesłychanej wagi: pułkownik Roja i oddziały polskie tworzące się samodzielnie

65 R. Starzyński, dz. cyt., s. 300-301.

66 CAW, Kolekcja generałów i osobistości - Roja Bolesław, Wniosek o nadanie Krzyża Niepodległości złożony 21 XII 1930; Z Legionów, „Ojczyzna i Postęp” nr 52, 11 VIII 1917, Warszawa, s. 19; B. Roja, Legendy..., s. 43; P. Hapanowicz, Generał Zymunt Zieliński (1858-1925). Szkic do portretu, Kraków 2012, s. 37.

67 Biblioteka Śląska - Katowice, Druki ulotne, sygn. U.R.54. Z dokumentów chwili. Rozłam w obozie rozbijaczy Legionów. I. Powróćcie do polskich szeregów! Apel Brygadiera Bolesława Roi. II. Odpowiedź zwolnionych oficerów LP, 16 XI 1917.

68 Szerzej: L. Mroczka, Galicji rozstanie z Austriq. Zarys monograficzny, Kraków 1990, s. $68-113$. 
w Galicji - dotąd mocno podejrzane - poddają się Radzie Regencyjnej i składają przysięgę wierności. Roja mianowany generałem brygady wojsk polskich i dowódcą brygady w Krakowie. Były oficer w wojsku austriackim, piłsudczyk, brutalny, śmiały, odważny kondotier, wsławił się w czasie wojny niejednym mężnym postępkiem, ale jest z tych co zrywają się do samodzielnego czynu, a nie trwają w karnym obowiązku”"69.

Już w okresie legionowym B. Roja przedstawiany był na rysunkach, obrazach czy w sztuce medalierskiej. Jeszcze w czasie walk II Brygady LP w Karpatach powstał portret mjr. B. Roi autorstwa Stanisława Janowskiego, korespondenta Biura Prasowego NKN. Dzięki sygnowaniu rysunku znamy datę i miejsce powstania tej pracy - 21 I 1915, Rafajłowa. W czasie formowania 4 pp w Piotrkowie Trybunalskim rysunek węglem z wizerunkiem dowódcy czwartaków wykonał Karol Maszkowski. Z 20 XII 1915 r. pochodzi rysunek ołówkiem autorstwa znanego artysty malarza Włodzimierza Wodzinowskiego. Portret opatrzony został podpisem „Bolesław Roja, dca 4 pp”. Z tego okresu pochodzi również znakomita podobizna podpułkownika wykonana czarną kredką i gwaszem przez Leonarda Stroynowskiego ${ }^{70}$.

Rok później powstała barwna grafika autorstwa Leopolda Gottlieba, przedstawiająca B. Roję siedzącego przy stole z założonymi rękami. Jak wynika z podpisu, portret wykonano pod Optową, w dniu 5 maja 1916. Seria 22 prac, z której pochodzi ta grafika, została odbita w zakładach Graficznych Johanna Edwina Wolfenbergera w Zurichu w 1916 r. (po wojnie wydała ją w 1936 r. Księgarnia Wojskowa w Warszawie). W tym samym roku Ignacy Pinkas namalował 2 olejne portrety B. Roi. W 1917 r. powstała jego karykatura autorstwa Kazimierza Sichulskiego. Artysta ukazał pułkownika na tle swojej ziemianki w Rojowym Osiedlu $^{71}$.

W 1916 r. Kazimierz Chodziński sportretował dowódcę czwartaków na prostokątnej plakiecie. Ten sam wizerunek znalazł się na bitych w srebrze oraz brązie medalikach o średnicy $21 \mathrm{~mm}$. Widać na nich głowę w profilu w lewo. Przy brzegu widnieje napis: Pułk. B. Roja. Natomiast wspomniany już J. Raszka, który pod koniec maja 1916 r. przyjechał na Wołyń, uwiecznił B. Roję na jednej ze swoich plakiet. Artysta widział w dowódcy 4 pp „uosobienie czwartackich tradycji”. Trzeba przyznać, że uchwycenie charakteru pułkownika udało się J. Raszce znakomicie $^{72}$.

Po odzyskaniu przez Polskę niepodległości B. Roja brał udział w obronie Lwowa, stając 16 XI 1918 r. na czele Grupy Operacyjnej „Wschód”. W czasie

69 Pamiętnik księżnej Marii Zdzisławowej Lubomirskiej 1914-1918, Poznań 2002, s. 698.

70 Nowe karty w dziejach Legionów, „Ilustrowany Tygodnik Polski” Z. 1, 1 VIII 1915, Kraków, s. 12; I będzie wolna Polska... Legiony Polskie w sztuce. Katalog, Warszawa 2008, s. 144; W. Milewska, M. Zientara, dz. cyt., s. 264, 362, il. 250.

71 MTN w Łodzi, Dział Zbiorów - Muzealia, sygn. M-6223/2. Grafika, L. Gottlieb - „Bolesław Roja”; M. Gałęzowski, dz. cyt., 280; W. Milewska, M. Zientara, dz. cyt., s. 232, 270.

72 M. Opałek, Pamiqtki polskie 1914-1917. Odznaki, medale, plakiety, z. 3, Kraków 1916, s. 30-31; J. Strzałkowski, Medale polskie 1901-1944, Warszawa 1981, s. 94; W. Milewska, M. Zientara, dz. cyt., s. 220, 360-361. 
wojny polsko-bolszewickiej dowodził 1 i 2 DP Legionów (1919 r.). Stał na czele Okręgu Generalnego Kielce i Pomorze (lipiec 1919-luty 1920). Następnie został dowódcą Pomorskiej Grupy Operacyjnej oraz 2 Armii (sierpień-wrzesień). W kwietniu 1920 r. otrzymał nominację na stopień generała porucznika. Był zwolennikiem prowadzenia rozmów, zarówno z Ukraińcami jak i Rosjanami. Z tego powodu, w wyniku interwencji premiera Wincentego Witosa, został pozbawiony dowództwa. W dniu 13 VII 1922 r. u B. Roi stwierdzono 50\% utratę zdolności do pracy, spowodowanej - jak to określono - służbą wojskową. Został zakwalifikowany jako inwalida i z dniem 1 X 1922 r. przeszedł w stan spoczynku. W 1923 r. zweryfikowano go jako generała dywizji ${ }^{73}$.

W okresie międzywojennym B. Roja - wspominany przez księżnę M. Lubomirską jako piłsudczyk - stał się oponentem marszałka. Jawnie występował przeciwko sanacji. Działał w Stronnictwie Chłopskim, z ramienia którego w latach 1928-1929 zasiadał w Sejmie. Następnie działał w Stronnictwie Ludowym. W 1937 r. przygotował list otwarty „,do legionistów i obywateli”, w którym wzywał do zmian systemowych, mających na celu demokratyzację życia społecznego $^{74}$. Z tego powodu generała nie dopuszczono do udziału w Zjeździe Związku Legionistów, organizowanym w tym roku w Krakowie. Najpierw aresztowany, następnie został umieszczony $\mathrm{w}$ szpitalu psychiatrycznym, gdzie pozostawał przez 2 tygodnie $^{75}$. W $1938 \mathrm{r}$. odrzucono wniosek o przyznanie generałowi Krzyża Niepodległości, uzasadniając: „,z powodu ujemnej opinii” ${ }^{\text {”6 }}$. Zatem informacja o posiadaniu przez B. Roję tego odznaczenia, podawana w większości haseł biograficznych, nie odpowiada rzeczywistości.

We wrześniu 1939 r. gen. B. Roja miał 63 lata. Był już wówczas schorowanym człowiekiem. Nie powstrzymało go to jednak od działalności podziemnej na rzecz Polskiego Czerwonego Krzyża. Prawdopodobnie to właśnie ona doprowadziła do jego aresztowania w marcu 1940 r. Był więziony na Pawiaku ${ }^{77}$, skąd

73 CAW, Kolekcja generałów i osobistości - Roja Bolesław, Karta rejestracyjna, II poł. 1922 - brak dokładnej daty; W. Cygan, dz. cyt., s. 137-138; A. Wojtaszak, Generalicja Wojska Polskiego 1918-1926, Warszawa 2012, s. 327, 815-816.

74 Słownik biograficzny działaczy ruchu ludowego. Makieta, Warszawa 1989, s. 346-347.

75 E. Kossewska, Zwiqzek Legionistów Polskich 1922-1939, Warszawa 2003, s. 117. W przygotowanej na zjazd odezwie B. Roja proponował zmiany na najwyższych stanowiskach państwowych. Jego zdaniem prezydentem powinien zostać I. Paderewski, a premierem W. Witos. Na tej podstawie uznano generała za osobę z zaburzeniami psychicznymi, gdyż „Trzeba być wariatem, żeby coś podobnego napisać”; A.J. Cieślikowska, dz. cyt., s. $172-173$.

76 CAW, Kolekcja generałów i osobistości - Roja Bolesław: Wniosek o nadanie Krzyża Niepodległości złożony 21 XII 1930 r. W 1933 r. na wniosku pojawiła się adnotacja, że „Komisja Legionowa proponuje Krzyż Niepodległości”. Sam zainteresowany w Kwestionariuszu z 19 X 1934 (CAW, Kolekcja generałów i osobistości - Roja Bolesław) - odpowiadając na pytanie dotyczące posiadanych odznaczeń - napisał: „zdaje się, że też Krzyż Niepodległości”. Wydaje się, że generał wiedział o pozytywnej opinii Komisji Legionowej i tym samym był pewien jego przyznania. Tymczasem na wspomnianym wniosku widnieje informacja, że wniosek został odrzucony w dniu 4 IV 1938.

77 ITS Digital Archive, Bad Arolsen, 1.2.2.1/11408019, Lista osób uwięzionych na Pawiaku z 2 V 1940, k. 2. 
3 maja został wywieziony i dzień później znalazł się w obozie koncentracyjnym w Sachsenhausen. Nadano mu numer obozowy 23982 ${ }^{78}$. Okoliczności jego śmierci przerażają. Niemcy - wiedząc, że to polski generał w stanie spoczynku („General ausser Diensten”) - szczególnie dręczyli B. Roję. Został zamordowany 27 V 1940 r. w bestialski sposób. Jak wspominał o. Henryk Maria Malak: „Generała Roję wykończono wczoraj na ulicy przed barakiem. Zadusił go młody esesman, przydeptując mu gardło. - Patrzcie! Tak kończy polski generał”79. Symboliczny grób B. Roi znajduje się na warszawskim cmentarzu Powązkowskim.

O tym, że pamięć o B. Roi trwa, świadczy tablica odsłonięta na osiedlu Nowy Bokowiec, w podwarszawskim Legionowie. Uroczystość miała miejsce 4 IX 2006 r. Generał uważany jest za „ojca chrzestnego” Legionowa. Taką bowiem nazwę nadał koszarom w Jabłonnie, oddając w ten sposób cześć polskim legionistom. Tablica pamiątkowa umieszczona jest na głazie. Można na niej przeczytać: Generał Bolesław Roja 1876-1940/ działacz niepodległościowy/ oficer legionów polskich i Wojska Polskiego/ inicjator nadania naszej miejscowości w 1919 roku nazwy Legionowo/mieszkańcy Legionowa 4 IX 2006. Ponadto w Legionowie B. Roja ma swoją ulicę. Ulica jego imienia jest także w Krakowie.

Postać pierwszego dowódcy legionowych czwartaków w pełni zasługuje na przypomnienie. Ten dzielny człowiek o bezkrompromisowych poglądach, wielokrotnie dawał przykład odwagi, zarówno wojskowej, jak i cywilnej. Do końca pozostał nieugięty, także w ostatnich dniach życia, godnie zachowując się wobec hitlerowskich tortur i upodlenia. Był przykładem dla podległych mu żołnierzy jak i współwięźniów hitlerowskiego obozu koncentracyjnego.

\section{Summary}

\section{Bolesław Roja. Legion Route of „Czwartacy” Commander}

The future commander of the $4^{\text {th }}$ Legions' Infantry Regiment was born on the $4^{\text {th }}$ of April 1876 in the village of Bryńce Zagórne, Autrian Galicia. He grew up in a family of the forester. He completed the Imperial and Royal St Ann's Gymnasium and in 1898 graduated from the Austro-Hungarian Army Cadet School (Kadettenschule) in Wiener Neustadt near Vienna.

In 1899 Bolesław Roja was promoted to second lieutenant. He served in the $36^{\text {th }}$ Land Defence Regiment (k.k. 36 Landwehrinfanterieregiment) in Kolomyia.

78 G.u.M. Sachsenhausen, Auskunf zu einem ehemaligen Häfling des KZ Sachsenhausen (11 VII 2014); W. Bartoszewski, Warszawski pierścień śmierci 1939-1944. Terror hitlerowski w okupowanej stolicy, Warszawa 2008, s. 117-118.

79 ITS Digital Archive, Bad Arolsen, 1.1.38.1/4080528, Akt zgonu B. Roi wystawiony 28 V 1940, Sachsenhausen - Oranienburg. Jako przyczynę śmierci podano anemię złośliwą; H.M. Malak, Klechy w obozach śmierci, t. 1, Londyn 1961, s. 169; w bazie danych w Muzeum w Sachsenhausen widnieją wspomniane 2 daty śmierci B. Roi, 27 i 28 V 1940 - G.u.M. Sachsenhausen, Auskunf zu einem ehemaligen Häfling des KZ Sachsenhausen (11 VII 2014). 
In 1905 he was transferred to army reserve. Before World War I he cooperated with the Austro-Hungarian intelligence.

In 1914 B. Roja joined the Polish Legions, at first in the $2^{\text {nd }}$ Legions' Infantry Regiment (the $2^{\text {nd }}$ Brigade of the Polish Legions). In March 1915 r. he was promoted to lieutenant colonel and appointed the commander of the $4^{\text {th }}$ Legions' Infantry Regiment which joined the $3^{\text {rd }}$ Brigade. The regiment was formed in Rozprza near Piotrków Trybunalski. In July 1915 B. Roja moved to the front to fight against the Imperial Russian Army. His regiment took a part in the battle of Jastków near Lublin (July 31-August 3, 1915) and later fought in the Volyn region.

In September 1915 B. Roja got promoted to the rank of colonel. In December his regiment was moved to Optowa by the Styr River were the camp of the Polish Legions was set up. It was called the "Roja's Camp". In the beginning of 1916 B. Roja organised the Colonel Council (Rada Pułkowników), a collective body of the Polish legionary officers. In July 1916 he took a part in the Battle of Kostyukhnivka (Kostiuchnówka) in the Volyn region.

After the Oath Crisis (Kryzys Przysięgowy) in July 1917 B. Roja left the Polish Legions and rejoined the Austro-Hungarian Army. In 1918 he returned to Kraków where he took over former Austrian Military Command (late October). In November 1918 he was promoted to brigade general and named the commander of Kraków garrison. He served in the Polish Army untill 1922 when he was transferred to reserve.

In 1928 B. Roja was elected to the parliament as a member of Stronnictwo Chłopskie peasant party. He frequently criticized Józef Piłsudski and sanacja government. In 1937 he was interned at the psychiatric ward of the Kraków military hospital.

In March 1940 the general was arrested by the Germans and placed in Pawiak prison in Warsaw. In May he was transferred to Sachsenhausen concentration camp, where he was murdered in a beastly way on the $27^{\text {th }}$ May 1940 .

Key words: Bolesław Roja, Polish Legions, First World War

Adres mailowy autorki: raffle77@gmail.com 


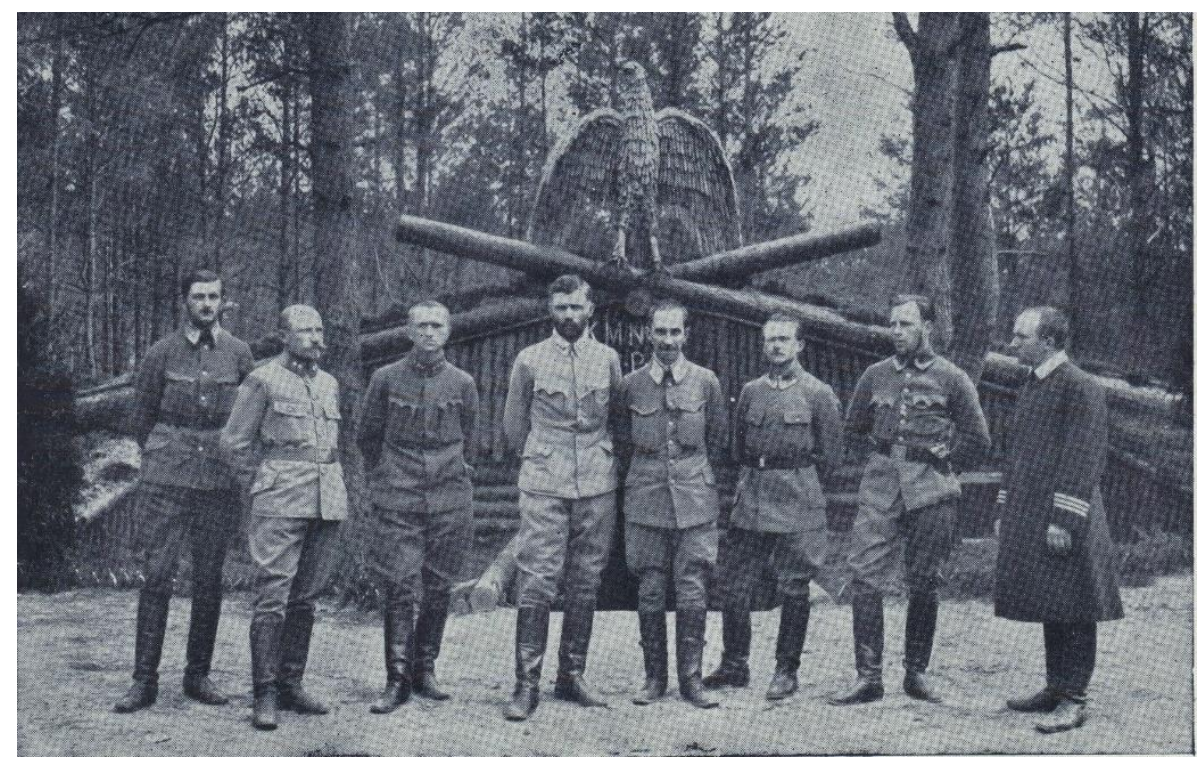

1. Płk Bolesław Roja (czwarty od lewej) przed komendą 4 pp. Rojowe Osiedle, Optowa 1916 r. Zbiory autorki.

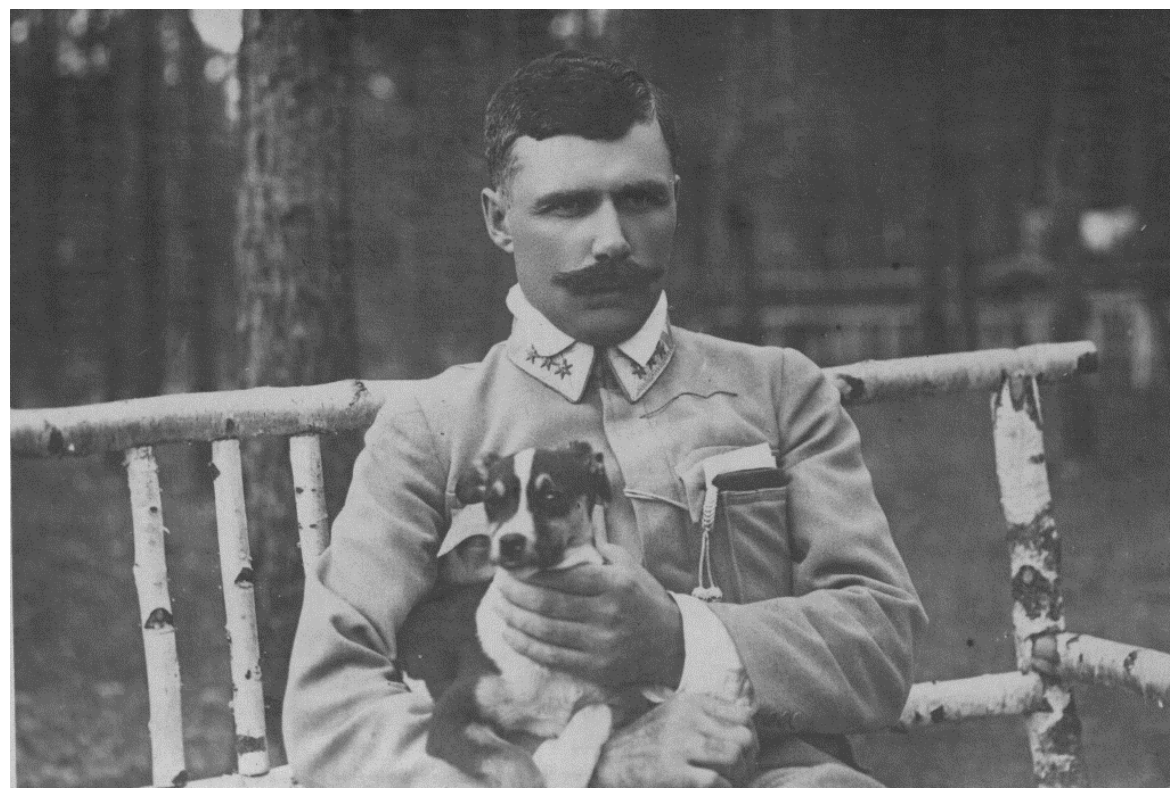

2. Płk Bolesław Roja, Optowa 1916 r. Zbiory autorki. 


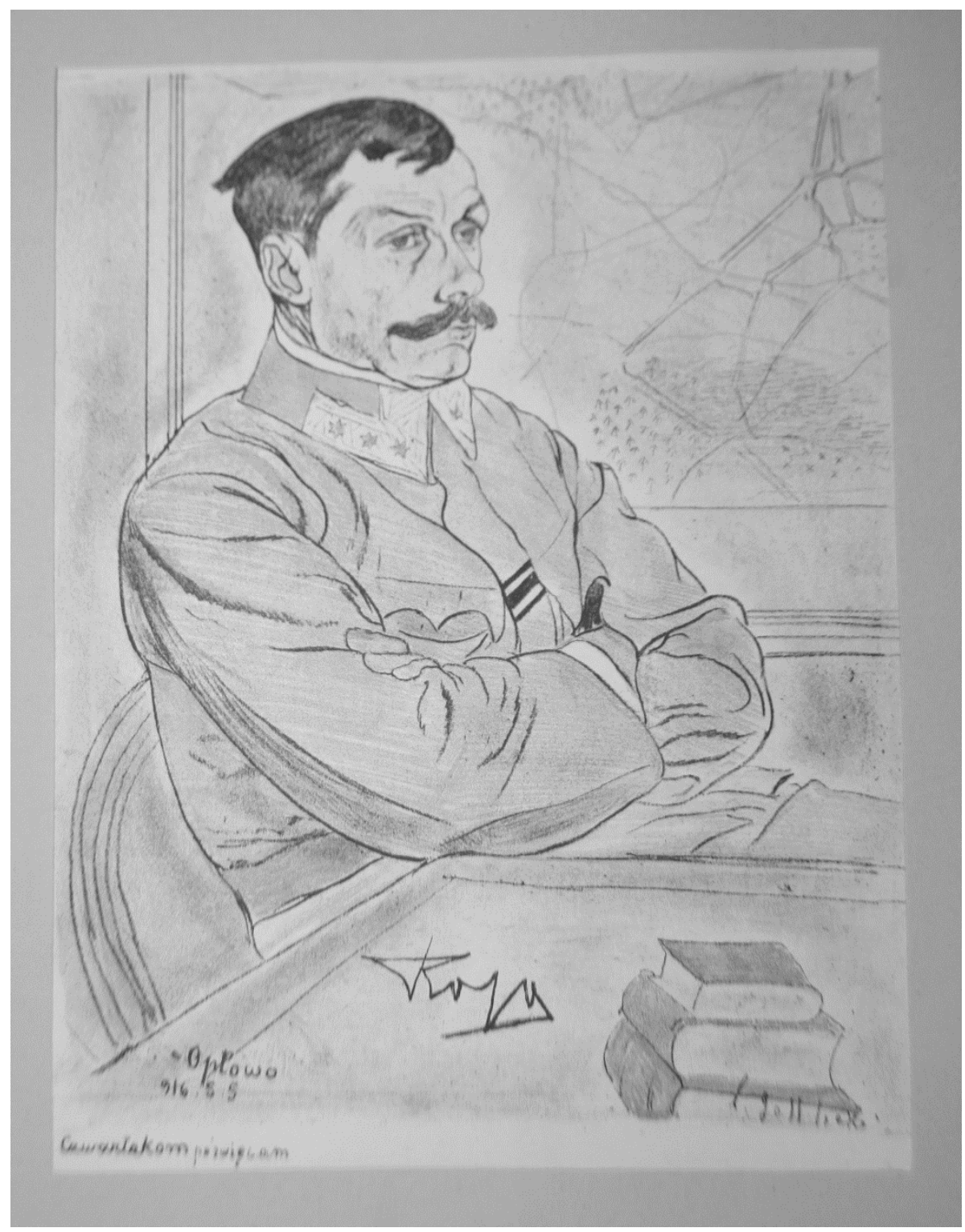

3. Litografia - Leopold Gottlieb „Bolesław Roja, Optowa 5 V 1916 r.” MTN w Łodzi. 